\title{
Analyzing the Environmental Changes of Natore's Gurudaspur Region due to Conversion of Agricultural Lands to Aquaculture Ponds
}

\author{
Farah Yeasmin, Raisa Bashar, Nazmul A. Khan
}

\begin{abstract}
For the district of Natore, in the last decade or so, aquaculture has played a significant role in improving the locals' socio-economic status. It is only in recent years that the negative impacts of unplanned pond-cutting have become profound and are introducing severe environmental and economic issues. This report encompasses the present status of Gurudaspur, Natore's villages of Nazirpur and Chapila unions where fish-farmers and agricultural farmers alike are facing problems such as water-logging, loss of agricultural land for crops and fruit trees and economic losses. For this study, ArcGIS is used to analyze the images to show the land transformation from 2001 to 2016 ; through participatory rural approach (PRA) and using investigations by the authors, it was validated that many agricultural lands were converted to fish ponds as the croplands could not stand the amounts of water that inundated the lands. It was also found that although the conversion rate was steady from 2001 to 2010 , between 2011 and 2016 almost half the remaining croplands were made into ponds. Although, till now, aquaculture is the primary and a good source of income for the Natore locals, without initiatives by government to restrict more unplanned pond-cutting and dissemination of training, as well as establishment of proper drainage canals, Gurudaspur will soon face several environmental, geographical and economic challenges. The research, furthermore, has important policy implications that need to be undertaken before the negative impacts result in irreversible damage to Natore's residents and its environment.
\end{abstract}

Keywords- aquaculture, water-logging, land use pattern, enviornmental impacts, Natore

\section{Introduction}

Aquaculture is the major economic source after agriculture, in Bangladesh. It is considered as one of the most productive and vital sector in the economy. It contributes 3.69 percent to the GDP and 22.60 per cent to the country's total agricultural products in 2015/2016 fiscal year (Bangladesh Economic Review 2015). The fisheries sector grew by 6.41 percent in 2014-15 whereas it was 6.36 per cent in 2013-14. Furthermore, the growth rate has been increased double in $2008-2014$ from $8.66 \%$ to $15.26 \%$ [1].

Like most of the districts in Bangladesh, economy of Natore is mainly dependent on aquaculture and crop production. Since demand for the fish is increasing with improved communication pond culture has been established as more profitable than crop production to farmers. Therefore, agricultural and other types of land are getting converted into fish ponds in Gurudaspur, Natore. The study area of four villages namely Brigarilla, Gopinathpur, Raninagar and Maharajpur is also going through transformation of land to aquaculture. By analysing Google image of three different years it was found that with the increase of pond, agricultural lands have been decreased

from 2001 to 2016 and changes of land use pattern became drastic from 2011 onwards.

However, land conversion without considering proper management leads to environmental damages in the long run. Almost half of the lands are covered by ponds at present whereas 15 years ago the pond or other water bodies were not the major component of land in the study area. An attempt is made in this study to map out the status of land conversion in four villages of Gurudaspur in last 15 years using geospatial techniques.

After field observation and surveys, negative impacts due to mass alteration of land have been found. People in this area has reported waterlogging as major problem along with decrease of fodder, high price of local species of fish and difficulties to cultivate crop and maintain orchards of fruit trees. It was also found that in some cases the land to pond conversion was forced as there was no other alternative but to convert due to the problem stated. This article tries to present changes in the ecological system, geography and agricultural challenges due to unmanaged land transformation.

\section{Background and Rationale}

The study area is situated in Gurudaspur Upazilla which consists of an area of $203 \mathrm{sq}$. km or 49341 acre (SID, 2012) [9]. Total study area is 4337.604 acre and is located between $24^{\circ} 23^{\prime} 60^{\prime \prime}$ and $24^{\circ} 20^{\prime} 14.4^{\prime \prime}$ north latitude and between $89^{\circ}$ 9' 51.71" and 89 9' 49.31" east longitude. People in this area are mostly involved in cultivation, fishing, livestock, fruit business etc. In Natore, pond culture is mostly practiced in semi-intensive system.

As pond based aquaculture is practiced in all the districts of Bangladesh; Natore plays a prominent role in this sector. To the farmers, freshwater culture is an attractive option over the conventional crop production. Hence, for the last one decade lands are getting converted into ponds in Gurudaspur. This mass conversion is going in unplanned way and brings unsustainable environmental consequences which will be severe in long term condition. At present, water logging is the biggest problem and it has impacts on socio-economic condition, livelihood. Due to water logging, those who are involved in agricultural activities are suffering most. As the land classes have changed and the canals and rivers get clogged, in monsoon the situation gets worse as the drainage system is not effective in this area. Therefore, this research has made an attempt to study the environmental consequences due to the land conversion and status of land use pattern in past and present using ArcGIS and Participatory Rural Appraisal (PRA) tools.

\section{Methodology}

The study area includes four villages of Natore, namely as Brigarila, Gurudaspur, Maharajpur and Raninagar. Information related to aquacultural practices and problems were collected by following PRA method which included individual interviews and focused group discussion; 35 interviews were done by targeting fish farmers from 20 to 60 years old and 4 focused group discussion were held including people with different age, gender and occupation to understand identify the environmental impacts, water logging crisis, problems in crop cultivation.

For the GIS/Temporal analysis the study has gone through three stages. 1) Image collection: High resolution 
satellite images were downloaded from Google Earth of the years 2001, 2011 and 2016. 2) Data preparation: Georeferencing the downloaded images which enables to analyse them with known co-ordinate system. At first, they are transformed to the Universal Transverse Mercator (UTM) map projection system, with datum D_WGS_1984. After Georeferencing, the study area was extracted according to previously created and projected shape file based on satellite images. For this operation, extraction tool of ArcGIS was used. 3) Data digitization: There are two basic methods of image classifications- supervised and unsupervised classification. In this study, a supervised classification method has been used. In a supervised classification, an image is classified using polygons that represent distinct sample areas of the different land use types to be classified (training samples). Therefore, supervised image classification-"maximum likelihood" technique is used to detect changes over the years. Four specific classes are taken for the classification: Pond area, land area, area covered by trees/orchard and miscellaneous. Area of each category was calculated by using cell size and using pixel counts of maps produced by ArcGIS. Cell size is the transformation from degree to decimal units then it is calculated in square meters. Lastly, the square meters converted into acre.

\section{Data Analysis and Findings}

- Water-logging and Impacts on Crop Cultivation: The adjacent lands of ponds are mostly affected due to water-logging since water seeps from ponds, keep the soil wet which makes the land unsuitable for cultivation. This problem becomes more frequent in recent $4 / 5$ years. Water does not go away due to continuous change of land use pattern, altitude level and canal stagnation. People in villages of Brigarila, Gopinathpur, Raninagar, Maharjpur reported that water stays around 5/6 months, in some places the duration is 8 months. During focused group discussion, it was found out that people in some places left their homestead due to waterlogging and shift somewhere with high elevation. However, immediately they cannot turn these places into ponds as it costs more to dig pond in those places because it was previously built on elevated land and of hard soil. So, the affected people usually make orchard or plant water tolerant species like coconut, plum and date. Therefore, affected farmers think it is wise to convert their lands into ponds. However, making pond requires certain amount of capital and basic size of land and situation is worse for those who cannot fulfill the requirements to start fish farming, neither can they make profit by cultivating land nor they do pond-culture.

- Impacts on orchards and vegetation: Betel leaf, mango, lychee, jackfruit orchards, mahogany, areca nut are found affected and dying in some places. Local people cannot grow vegetable according to their demand because of less survival tendency of tress and vegetation disappearance due to waterlogging. Although, it has been observed that pond dykes are used for banana, papaya, date palm, coconut and vegetable plantation. According to the farmers earthen pond dykes are suitable for vegetables. From focused group discussion it was found that farmers do not plant tresses that have smaller leaf since smaller leaves is hard to remove from pond and decomposition of left leaves can create excess nutrient in pond by decreasing dissolved oxygen. Similar kind of link has been found in a study by Holgerson \& Skelly (2016) in "Reconciling the role of terrestrial leaves in pond food webs: a whole - ecosystem experiment." According to their study terrestrial leaves provided nutrients to algae [5].

- Impacts on livestock and poultry: Increase of pond area has impacts on livestock and poultry. Since grazing land has been reduced in the area, people face difficulties to raise cattle, goat and sheep. They have to bear the extra costs to feed them. Another study based on Kapasia, Gazipur by (Thompson et al., 2003) investigated that people in that particular area are not interested to keep livestock because fodder prices have risen [8]. It is observed that fishfarmers do not allow ducks in their ponds as they spread disease such as skin diseases to farmers and disperse pest, pollute pond water with their dropping. Andrikovic \& Gere (1992) showed the effects of ducks on eutrophication in the paper "Effects of waterfowl on water quality" and Fleming and Fraser (2001) discussed about "fecally derived" bacteria and impacts of nutrient in water quality[4][2]. It is also observed less presence of shrub or bushy area in those villages particularly pond areas in Maharajpur had less aquatic plants and pond dykes were clean. It may impact chickens as less forage area means less food.

- Canal stagnation and soil erosion: Physical alternation of lands by creating ponds, breaks the water connectivity to the canals and rivers. Less vegetation cover, reduction of grazing land creates soil erosion and siltation in canals and drains. People in Maharajpur constructed a one 4 to $5 \mathrm{~km}$ long canal to solve the water logging problem, voluntarily.

- Impacts on local fish biodiversity: Natural freshwater fish species are not available and price is comparatively higher than cultured fish. Fish diversity has declined and people consume more cultured fish than previous years. Since many nonnative species like carp species is being cultivated in ponds commercially escape of these species can have negative impacts on fish diversity. Flowra et al., 2013 concluded their study that freshwater species in Natore is declining and $55 \%$ species are less available where $13.33 \%$ and $8.33 \%$ fish species are under "rare" followed by "very rare" category. It was also showed in their research that cultural species has less fungal diseases than non-cultural species in Natore[3].

- Changes in local biodiversity and ecosystem: Less visibility of common medicinal plants and herbs such as Hyptis suaveolens, country mallow - Sida cordisfolia, Pergularia daemia,, Aloe indica, Andrographis paniculata, Azadirachta indica in the study area. Disappearances of traditional medicinal plants in Natore also reported by Rahmatullah et al. (2012)[6]. Studies found on ecotoxicological risks associated with chemicals and potential antibiotic resistance in aquatic microorganism and its impacts on receiving water (Redshaw,1995)[7]. Also aquatic 
organisms like algae, duckweed, microorganisms in sediments, soil organisms like earthworm, fungi, bacteria, and terrestrial organisms like mouse, bees, insects like bees, mayfly can be exposed due to use of chemicals in water and pond edge.

According to farmers, in the study area, specially villages in Brigarilla and Gopinathpur, people witness number of snake of different species like Xenochrophis piscator or Checkered keelback, Varanus bengalensis and other nonvenomous water snake. Snakes usually eat fish, mouse and frogs. Numbers of rats and mice along with stray dogs, fox have been increased in the study area. Rats create hole in bottom and cause water loss. Therefore, ponds in the study area may attract the predatory species like snake. Another fact found during focused group discussion was that birds like Cattle Egret (Bubulcus ibis), herons, kingfishers, kite birds, water fowls and fish eating owls have not been seen like previous years.

\section{Crop cultivation is gradually} being replaced by commercial aquaculture in the study area.

\section{Intensification and scientific} practice of aquaculture instead of expansion of land is necessary for sustainable aquacultural practices.

- Changes in physiography and land use pattern: Land class have been altered. The higher lands that used to cultivate crops are turned into ponds and affecting the adjacent areas.

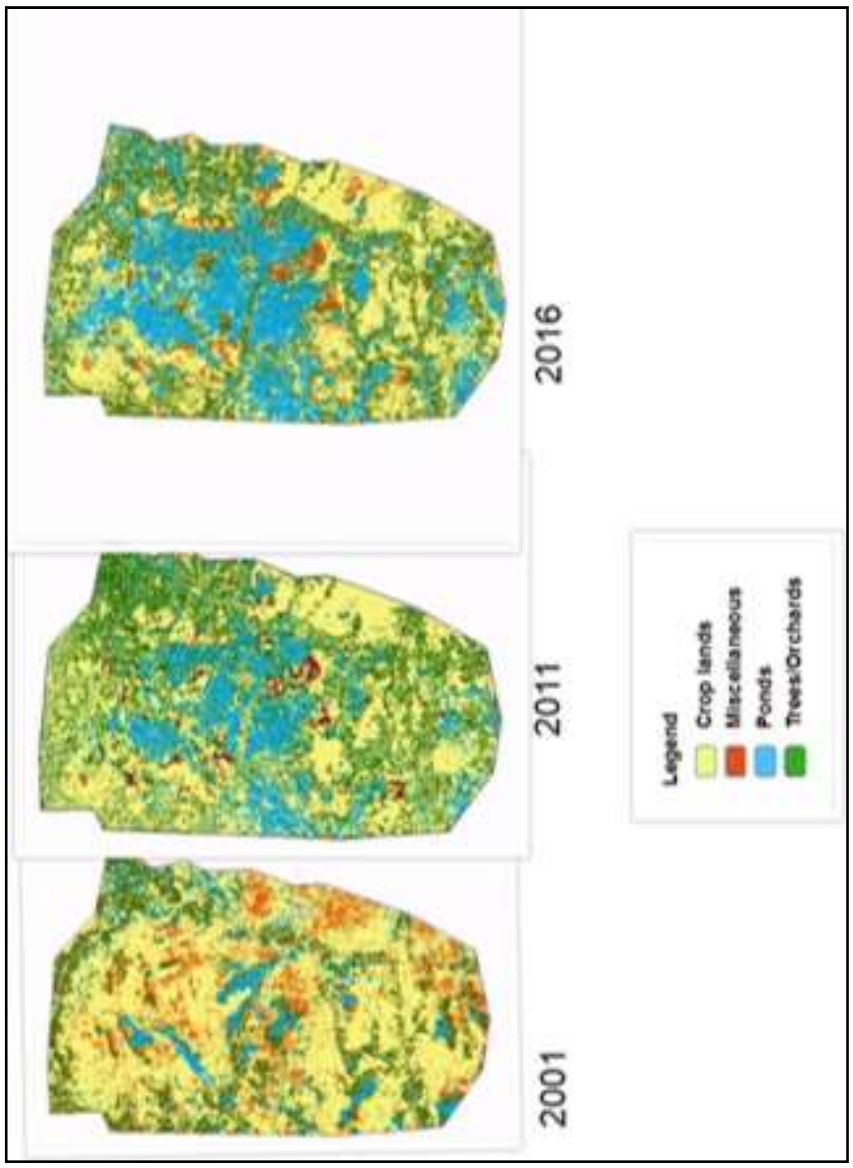

Figure 1: Changes in land cover from 2001 to 2016. (Maps are generated by ArcGIS 10 and Image source: Google Earth Pro)

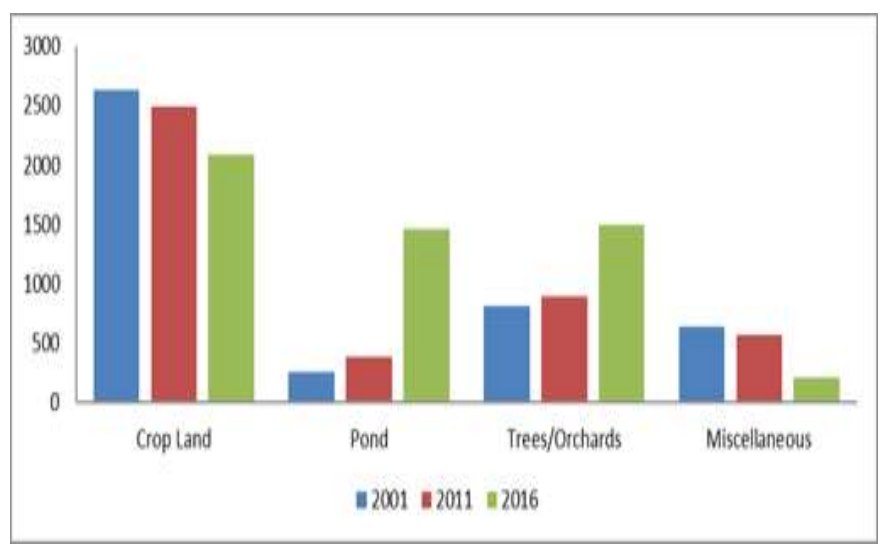

Figure 2: Land use pattern from 2001 to 2016 (area in acre)

Figure 1 and 2 shows that major amount of land in the study area is used for crop cultivation, although land availability for cultivation decreased gradually between 2001 and 2016; Both the maps and graphs also show gradual increase of ponds from 2001 to 2016 and a dramatic increase from 2011 onwards till 2016; it almost seems forced. 


\section{Recommendations}

Since commercial aquaculture is growing without any planned management and any unplanned development will raise the concern of sustainability issues. Hence, different problems due to physical alteration of the study area have been observed. Through key information initiative session (KII) with district fisheries officer, discussion session with local people and fish farmers it has been identified that full potential of aquaculture has not yet been recognized and environmental problems are increasing.

On that account, recommendations are given on this section based upon the filed observation and discussion session that can improve the aquacultural practice and production and reduce the environmental impacts.

1) To mitigate the waterlogging, establishment of new canals and clearing the existing clogged drains, canals and water path to the rivers is required. People in Maharajpur, have established a one $\mathrm{km}$ long canal by themselves and reduced the problem of water logging.

2) There is an order from the government in Natore region to not build new ponds, but it is necessary to strengthen the monitoring system.

3) Pond cutting on high lands should not be encouraged.

4) Creating awareness among villagers about the environmental impacts of unsustainable pond cutting.

5) Diversifying fish species to culture and encouraging farmers to cultivate local fishes.

6) Intensification and scientific practice aquaculture than expanding should be the approach. Therefore, NGOs and government can assist farmers to improve seed and feed quality, offer technical support and skill enhancement education and training.

\section{Conclusion}

As this sector is not scientific and farmers are not fully aware of environmental impacts, in the long run the soil and water quality will be degraded. Furthermore, concentrating on fast growing profitable fish species will lead to local fish diversity loss. Therefore, farmers should be encouraged to utilize their resources in effective way than expanding the pond areas. So, government and other organizations should give attention on these issues to promote environmentally sustainable aquaculture practice.

\section{Acknowledgment}

We, the authors, are firstly grateful to the Almighty and our family and friends for the strength, support and encouragement we received from them throughout the course of the project. We would also like to express gratitude to the Environmental Science and Management department of North South University for the opportunity to initiate and conduct the project.

\section{References}

[1] Bangladesh Economic Review (2015). Ministry of Finance. doi://www.mof.gov.bd/en/budget/15_16/ber/en/Ch-02.pdf doi://www.mof.gov.bd/en/budget/15_16/ber/en/Ch-07.pdf.

[2] Fleming, R., \& Fraser, P. E. H. (2001). The impact of waterfowl on water quality. Literature Review. Ontario: Ridgetown College, University of Guelph.

[3] Flowra, F. A., Islam, M. A., Jahan, S. N., Hussain, M. A., Alam, M. M., Bashir, F. A. \& Simon, K. D. (2013). Status and decline causes of fish diversity of Baral River, Natore, Bangladesh. Aquaculture, Aquarium, Conservation \& Legislation-International Journal of the Bioflux Society (AACL Bioflux), 6(4).

[4] Gere, G., \& Andrikovics, S. (1992). Effects of waterfowl on water quality. Hydrobiologia, 243(1), 445-448

[5] Holgerson, M. A., Post, D. M., \& Skelly, D. K. (2016). Reconciling the role of terrestrial leaves in pond food webs: a whole - ecosystem experiment. Ecology, 97(7), 1771-1782.

[6] Rahmatullah, M., Khatun, Z., Hasan, A., Parvin, W., Moniruzzaman, M., Khatun, A. \& Jahan, R. (2012). Survey and scientific evaluation of medicinal plants used by the Pahan and Teli tribal communities of Natore district, Bangladesh. African Journal of Traditional, Complementary and Alternative Medicines, 9(3), 366-373.

[7] Redshaw, C. J. (1995). Ecotoxicological risk assessment of chemicals used in aquaculture: a regulatory viewpoint. Aquaculture Research, 26(9), 629-637.

[8] Thompson, P., Sultana, P., \& Khan, A. (2003). Aquaculture extension impacts in Bangladesh: A case study from Kapasia. Gazipur. Technical Report 63. WorldFish Center, Penang.

[9] SID (2012). Community Report Naotre Zilla (2011). Statistics and Informatics Division (SID). Ministry of Planning, Dhaka,Bangladesh.

About Author (s):

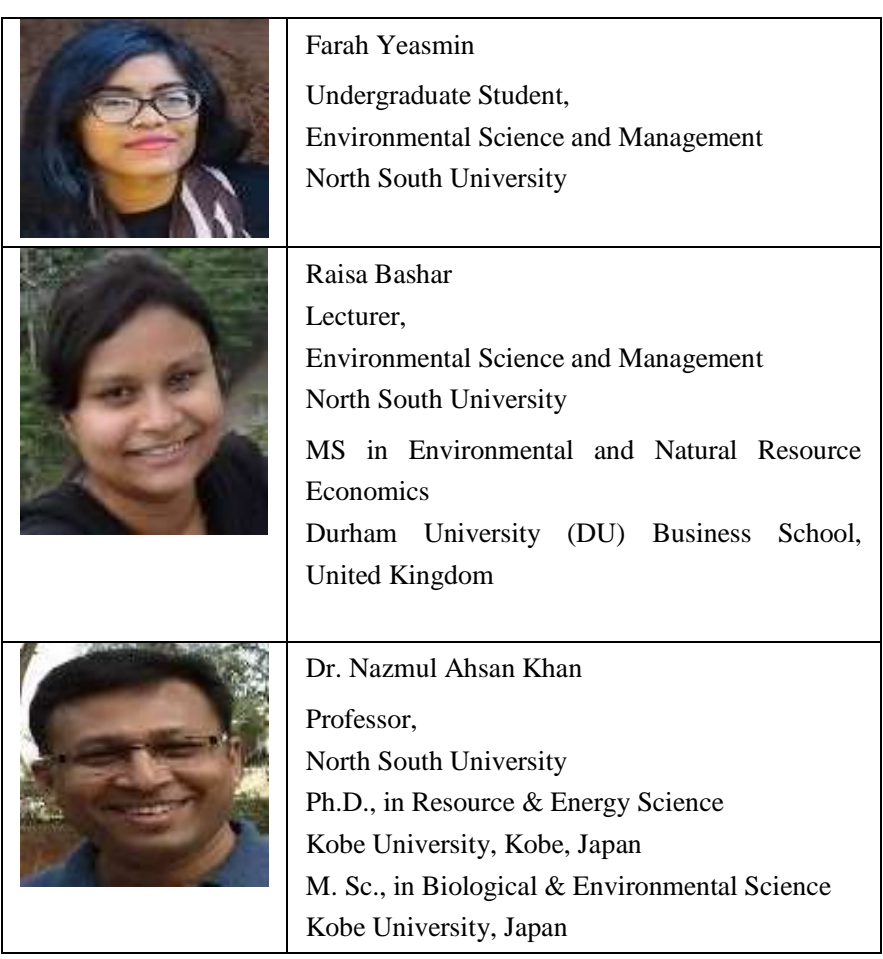

